\title{
Promoting Interventions to Develop Religous Identity of Secondary School Students
}

\author{
Galuh Prawitasari ${ }^{*} 1$, Suwarjo ${ }^{2}$ \\ Universitas Negeri Yogyakarta \\ ${ }^{*}$ Corresponding author, $\equiv$ e-mail: prawitasari.galuh@gmail.com
}

\begin{abstract}
Adolescence is known as the transition from childhood to adulthood. In this period, the adolescent will experience many changes related to their identities in various domains of life, including the religious domain. This study aims to investigate the profiles of religious identity status of early adolescents. A total of 116 secondary school students participated in this study. Data were collected by using the Scale of Religious Identity Status. The results showed that students' religious identity statuses were distributed in four categories: achievement $(66 \%)$, searching moratorium $(23 \%)$, foreclosure $(10 \%)$, and moratorium $(1 \%)$. Implications for guidance and counseling services in secondary school are discussed to promote the development of religious identity of early adolescents.
\end{abstract}

Keywords: religious identity, secondary school, guidance and counseling.

How to Cite: Prawitasari, G., \& Suwarjo. (2018). Promoting Interventions to Develop Religous Identity of Secondary School Students. Couns-Edu: International Journal of Counseling and Education, 3(4): pp. 140-146. DOI: https://doi.org/10.23916/0020180314640 reproduction in any medium, provided the original work is properly cited. (C2018 by author.

\section{Introduction}

Adolescence is a period of identity search. At this period, adolescents will be exposed to many roles and encounter various issues about who they are, what is important to them, and what they want to address in life. Erikson (1968) was the first to realize how central such as questions are to understand adolescent development. Adolescents able to deal with conflicting roles and identities will have a new and acceptable awareness of themselves, while teenagers who fail through an identity crisis will experience a confusion of identity (Santrock, 2014).

The work of Erikson, identity, further investigated by Marcia (1993). He extended Erikson's concept of identity and concluded the four types of adolescent's identity statuses based on the amount of explorations and commitments that adolescents experience or have experienced. Exploration refers to the active questioning and weighing of various identity alternatives before deciding about the values, beliefs, and goals to pursue. Commitment involves making a firm choice about an identity domain and engaging in significant activities geared toward the implementing of that choice (Crocetti et al., 2008).

The four Marcia's identity statuses are diffusion, foreclosure, moratorium, and achievement. These identity statuses represent the way adolescents deal with their identity crises and the extent of adolescents' exploration and commitment. Specifically, in the diffusion status adolescents have not engaged in a proactive process of exploration of different alternatives, nor have they made a commitment in a specific 
identity domain. In the foreclosure status, adolescents have made a commitment without exploration. In the moratorium status, adolescents are actively exploring various alternatives and have not yet made a commitment. In the achievement status, adolescents have made a commitment to a specific identity domain, following a period of active exploration (Crocetti et al., 2008). Papalia \& Feldman (2015) argued that adolescent in diffusion status does not have a high degree of seriousness in considering choices and also avoid commitment. Conversely, an adolescent who has made a choice and expressing his commitment to his choice is said to have an achievement status.

The original concept of Marcia's identity status further elaborated by Crocetti et al.(2008) who extended Marcia's previous two-dimensional model (commitment and exploration) to the threedimensional model (commitment, in-depth exploration, and reconsideration of commitment). Their recent work was based on empirical evidence which revealed two contrasting facets of this status.

The moratorium is defined, theoretically, as a positive or adaptive status in the developmental trajectory from diffusion to achievement. The positive aspect of the moratorium is consistent with findings demonstrating that individuals in this status were similar to their peers in the achievement status on a number of variables, such as autonomy, moral reasoning, low authoritarianism, and warm, intimate relationships (Crocetti et al., 2008). On the other hand, the moratorium is defined as the status indicative of an "identity crisis". Previous research has consistently demonstrated that being in the moratorium status is accompanied by some negative characteristics, such as the highest level of depression and substance use(Luyckx et al., 2005),elevated existential anxiety (Berman et al., 2006; Crocetti et al., 2009), lower levels of adjustment (Luyckx et al., 2008). The moratorium status also tend to be more neurotic ans less extraverted, open, and agreeable while conversely for adolescents with strong commitments (Meeus, 2011).

The three-dimensional model results to five, rather than four identity status. The achievement status would be characterized by high commitment, high in-depth exploration, and low reconsideration of commitment. The foreclosure status would be characterized by high commitment, low to moderate indepth exploration, and low reconsideration of commitment. The moratorium status would be characterized by low commitment, low in-depth exploration, and high reconsideration of commitment. The diffusion status would be characterized by low commitment, low in-depth exploration, and low reconsideration of commitment. Finally, the fifth new status, searching moratorium, would be characterized by high commitment and high in-depth exploration (as for the achievement status) but also high reconsideration of commitment (as for the moratorium status).

Several findings from recent studies have demonstrated the correlation between identity status in adolescence and psychological well-being. Adolescents with achieved identity status show high scores in various aspects of psychological function (such as self-esteem, internal locus of control, psychological wellbeing, satisfaction of life, realization, and adjustment). The "achieved" adolescents also have a positive personality profile and a high level of awareness and emotional stability. In contrast, adolescents with diffusion identity status have low self-esteem, internal locus of control, and psychological well-being scores and show a high tendency to engage in antisocial behavior and health-related risk behaviors, such as drug abuse (Schwartz et al., 2011; Meeus, 2011).

The identity status of adolescents in a domain may differto any other domains (Goossens, 2001; Fadjukoff, Pulkkinen, \& Kokko, 2005). An adolescent can have achieved identity status on a single domain, but diffused on other domains. There are at least eight identity status domains that commonly studied by recent scholars. According to Marcia (2001), one of the strategies to choose a domain is by assessing the domain that considered being important in a certain period.

Religious is an ideological domain that considered to be important in adolescence. An individual may be examining self-definition attributes in domains such as vocational choice, ideology, sexuality, family roles, and/or sex-role preference during this period (Marcia, 1993). In addition, a thorough understanding of adolescents' religious experiences is important given the substantial identity development that occurs during this period (Fowler \& Dell, 2006). Cohen-Malayev et al. (2014) refer the term of religious identity to an individual's religious self-definition and to the significance ascribed to religion in 
one's self-definition, whereas Grifftih \& Griggs (2001) specifically defined religious identity status as a conceptual framework defined by exploration and commitment within the specific domain of religion.

Religious identity as well has been proved to relates positively to psychological well-being parameters (e.g. Abu-Rayya \& Abu-Rayya, 2009; Francis \& Katz, 2002; Francis \& Robbins, 2000; Hackney \& Sanders, 2003; Helm, Hays, Flint, Koenig, \& Blazer, 2000; Koenig \& Larson, 2001; Leondari \& Gialamas, 2009; Lewis, Maltby, \& Day, 2005;Swinton, 2001), self-esteem, positive affect, and meaningfulness (Davis \& Kiang, 2016; Chan, Tsai, \& Fuligni, 2014). These studies affirm the importance of religious domain to the identity development in adolescence.

The aim of this study is to investigate the profiles of religious identity status of early adolescents. It is important to figure out the religious identity status since it was related positively to many psychological well-being parameters. By mapping adolescent's religious identity status, the guidance and counseling teacher can propose several appropriate interventions to foster the development of religious identity into achievement status.

\section{Method}

\section{Participants}

The participants of this study were 116 secondary school students in Sleman, Yogyakarta. The age range of student participant was $12-17$ years $(\mathrm{M}=14.19, \mathrm{SD}=.99)$.

\section{Instruments}

Religious identity status was measured by using the Religious Identity Status Scale (RISS). RISS was based on Five Identity Status Model (Crocetti, et al., 2008) which consist of 38 items ( $\alpha=.663)$. The favorable items were responded to a 4-point scale from 1 (strongly disagree) to 4 (strongly agree) and conversely for the unfavorable items. The measure is comprised of three subscales, including commitment (21 items), in-depth exploration (11 items), and reconsideration of commitment (6 items).

\section{Data Analysis}

There are two main processes of the data analysis. First, descriptive statistic analysis is employed to determine the religious identity status of each participant. The participant's total score of each subscale will be categorized as high or low based on criteria below.

Table 1. Categorization of Participant's Scores

\begin{tabular}{ccc}
\hline Subscale & Level & Score \\
\hline Commitment (Co) & High & $52.5-84$ \\
& Low & $21-52$ \\
In-depth Exploration (IE) & High & $27.5-44$ \\
& Low & $11-27$ \\
Reconsideration of Commitment (RC) & High & $16-24$ \\
& Low & $0-15$ \\
\hline
\end{tabular}

Based on score's level above, the participantwill be classified into one of five identity statuses (achievement, searching moratorium, moratorium, foreclosure, or diffusion) based on criteria of table 2 .

Table 2. Religious Identity Status Classification

\begin{tabular}{cc}
\hline Status & Level of Scores \\
\hline Achievement & High Co, high IE, low RC \\
Searching Moratorium & High Co, high IE, high RC \\
Moratorium & Low Co, high IE, high RC \\
Foreclosure & High Co, low IE, low RC \\
Diffusion & Low Co, low IE, low RC \\
\hline
\end{tabular}




\section{Results and Discussions}

The The descriptive statistic analysis of Religious Identity Scale revealed that majority of students were in achievement religious identity status $(66 \%)$. The second majority students were in searching moratorium status (23\%), while only few students were in foreclosure status $(10 \%)$ and moratorium status $(1 \%)$. None of students represented the diffusion status.

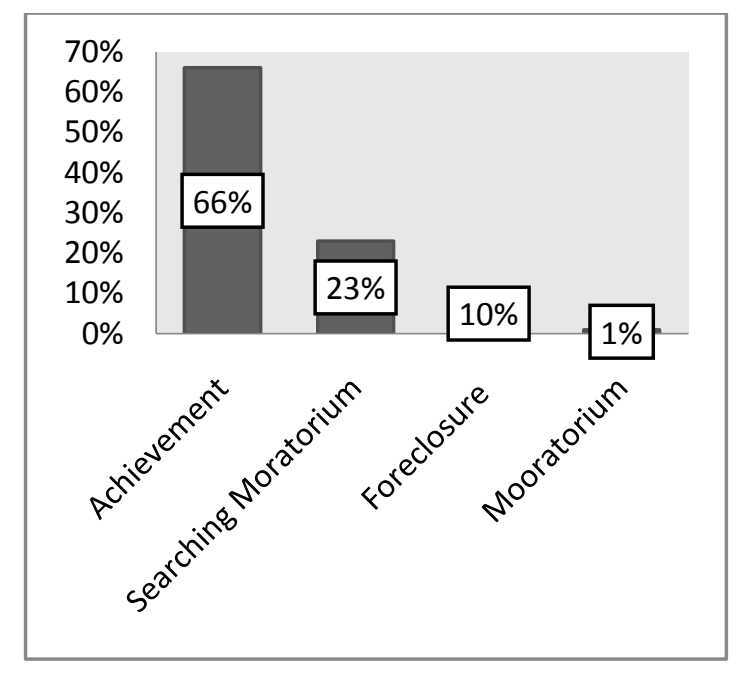

Figure 1.

Religious Identity Status Profiles of Secondary School Students in Sleman, Yogyakarta

Each of the statuses represent its specific psychosocial problems. Adolescents in achievement and foreclosure status are characterized by low levels of psychosocial problems and indicated a condition of identity stability. However, the foreclosure adolescents are less extroverted, agreeable, conscientious, and open to experience than adolescents in achievement. On the other hand, adolescents in searching moratorium and moratorium status report more psychosocial problems, both internalized and externalized behaviors. Therefore, these two types of the moratorium represent a condition of identity instability, which is indicated by the high symptoms of depression and anxiety. However, the moratorium adolescents appeared to be much more troubled than the searching moratorium cluster, as revealed by higher scores on several psychosocial problems (Crocetti et al., 2008).

Although adolescents in achievement status were the healthiest individuals as they indicated lower psychosocial problems than any other identity status, the existence oftheir current statuses may change as the characteristic of identity formation during adolescence and early adulthood is not permanent for later life periods (McAdams \& Cox, 2010). According to Marcia (1994 in Santrock, 2014), many adolescents who have developed a positive identity follow the "MAMAcycle"; that is, their identity statuses change from moratorium to achievement to moratorium to achievement. This cycle may recur throughout their lives. Marcia (2001) also noted that the first identity status which is formed by an adolescent is not a final identity for him.

Adolescents who encounter the "MAMA cycle" will enter a moratorium status before finally achieving a return status. At this moratorium status, adolescents will experience an identity crisis which defined as a period to sort through some meaningful and available alternatives to a certain domain. As a result, adolescents with moratorium status will tend to experience an instability of identity. Therefore, it is important to suggest apropriate intervention, which aims to prevent the achieved adolescents from a condition of prolonged identity instability.

One of the preventive interventions in Guidance and Counseling is a group guidance. Prayitno \& Amti (2004) defined guidance as a service delivered by an expert (counselor) for one or group of people 
(counselee) in order to facilitate the development of their own self-supporting abilities. Specifically, Regulation of the Minister of Education and Culture Number 111/2014 about Guidance and Counseling for Elementary and Secondary Schools elucidate group guidance as for the provision of assistance for students (counselee) through small groups of two to ten people in order to prevent any potential problem and to maintain or develop necessary students' life skills. A type of group counseling services which enacted as a prevention effort for adolescents in achievement is a group discussion technique. A counselor or Guidance and Counseling teacher divide the achieved students into several groups and discuss a topic about nurturing the healthy religious identity.

Adolescents in searching moratorium status differ only in reconsideration of commitment aspect than adolescents in achievement status. A searching moratorium adolescent characterized with a high level of reconsideration of commitment. In contrast, those in achievement status have a low reconsideration of commitment. A high level of reconsideration of commitment indicates a decrease of satisfaction toward adolescents' current commitment. However, adolescents in searching moratorium status will continue to carry on the process of in-depth exploration. This condition may lead to a state of identity instability. Therefore, the curative type of Guidance and Counseling service is needed by providing a person-centered approach for individual or group counseling.

According to person-centered approach, psychological problems arise as a result of discrepancies between ideal-self and real-self of the counselee. The role of the counselor is to help the counselee to minimize or even eliminate the discrepancies. With regard to the religious identity status, a counselor will help the counselee to identify the ideal-self-image of his or her current religiosity as well as the real-selfimage. The counselor then seeks to create a counseling atmosphere filled with unconditional positive regard and provides an accurate empathetic understanding of the disequilibrium condition experienced by the counselee. In addition, the counselor also needs to express a genuine to impose the normative restrictions of the counselee's dissatisfactions.

Foreclosure identity status is characterized by the high level of commitment and the low level of indepth exploration and reconsideration of commitment. Consequently, the foreclosure adolescents tend to conform to the values shared by the surrounding environment. They are more reluctant to explore deeply their current religious choices because they think that they would feel guilty and anxious if they tried to do such a deep exploration (Marcia, 1993).

An adolescent with foreclosure religious identity status would encounter a spiritual conformity. According to Griffith \& Griggs (2001), spiritual conformity is the adoption of religious beliefs and behaviors to gain acceptance from others. At this level of spiritual formation, motivation is still external and self-serving. Adherence to religious beliefs tends to be superficial and compartmentalized due to a lack of rigorous critique and evaluation. Therefore, the required Guidance and Counseling service for the foreclosure adolescents are a service which aims to enhance adolescents' self-confidence. The goal is to make them able to explore their religious beliefs deeply without any feelings of guilt or anxiety.

A school counselor may use a variety of techniques to enhance the adolescent's self-confidence, such as the asserivve training. According to Bishop (1999) assertiveness will develop self-confidence and self-ability to judge, argue, and respect others. Other recent studies have been shown that assertive training can be applied to improve students' self-confidence (Asrowi, Chadidjah,\& Utami, 2017; Turina, Giyono, Rahmayanti, 2015; Indrawati, Setyorini, \& Padmomartono, 2014).

The basic assumption of assertive training is that everyone has the right to express his feelings, opinions, beliefs, and attitudes to do things without any hesitation but does not hurt the feelings of others. Assertive training is a social-skill exercise given to an anxiety-plagued individual, unable to defend his rights, too weak, letting others undermine him, unable to express his temper properly and quickly offended (Corey, 2009). 


\section{Conclusions}

The results showed that students' religious identity statuses were distributed in four categories: achievement (66\%), searching moratorium $(23 \%)$, foreclosure $(10 \%)$, and moratorium $(1 \%)$. The recommendations of Guidance and Counseling services for adolescents with their respective religious identity statuses are: (1) group guidance services about the development of a healthy religious identity for adolescents with achievement status; (2) individual or group counseling services by a person-centered approach for adolescents with searching moratorium and moratorium statuses; and (3) individual or group counseling services by assertive training technique for adolescents with foreclosure status.

This study only employed participants in early adolescence. It is important to draw more participants in the middle as well as late adolescence to capture a more complete description about the development of religious identity status in adolescence. Moreover, it is also necessary for a further researchers to consider more specific about adolescent's contexts (e.g. residency and culture) since it was proved to be highly related to adolescent identity development.

\section{References}

Abu-Rayya, M. H., \& Abu-Rayya, H. M. (2009). Ethnic identification, religious identity, and psychological well-being among Muslim and Christian Palestinians in Israel. Mental Health, Religion \& Culture, vol. 12, 147-155.

Asrowi, Chadidjah, \& Utami, F. P. (2017). Implementasi Teknik Assertive Training untuk Meningkatkan Self-Confidence Siswa Sekolah Menengah Pertama di Kabupaten Karanganyar. Jurnal Ilmiah Pesantren, 3(1), 341-354.

Berman, S., Weems, C., \& Stickle, T. (2006). Existential anxiety in adolescents: Prevalence, structure, association with psychological symptoms in identity development. Journal of Youth and Adolescence, 35, 303-310.

Bishop, S. (1999). Assertiveness Skills Training. New Delhi : Viva Books Pivated Limited.

Chan, M., Tsai, K. M., \& Fuligni, A. J. (2014). Changes in religiosity across the transition to young adulthood. Journal of Youth and Adolescence, no. 44, vol. 8, 1555-1566.

Cohen-Malayev, M., Schachter, E. P., \& Rich, Y. (2014). Teachers and the religious socialization of adolescents: Facilitation of meaningful religious identity formation processes. Journal of Adolescence, vol. 37, 205-214.

Corey, G. (2009). Teori dan Praktek Konseling dan Psikoterapi. Bandung: PT. Refika Aditama.

Crocetti, E., Klimstra, T., Keijsers, L., Hale, W., \& Meeus, W. (2009). Anxiety trajectories and identity development in adolescence: A five-wave longitudinal study. Journal of Youth and Adolescence, 38, $839-849$.

Crocetti, E., Rubini, M., Luyckx, K., \& Meeus, W. (2008). Identity Formation in Early and Middle Adolescents From Various Ethnic Groups: From Three Dimensions to Five Statuses. Journal of Youth and Adolescence, vol. 37, 983-996.

Davis, R. F., \& Kiang, L. (2016). Religious Identity, Religious Participation, and Psychological WellBeing in Asian American Adolescents. Journal of Youth and Adolescence, vol. 45, 532-546.

Erikson, E. H. (1968). Identity : Youth and crisis. New York : Norton.

Fadjukoff, P., Pulkkinen, L., \& Kokko, K. (2005). Identity processes in adulthood: diverging domains. Identity: An International Journal of Theory and Research, vol. 5, 1-20.

Fowler, J. W., \& Dell, M. L. (2006). Stages of faith from infancy through adolescence: Reflections on three decades of faith development theory. Dalam E. C. Roehlkepartain, P. E. King, L. Wagener, \& P. L. Benson (Eds.), The handbook of spiritual development in childhood and adolescence (pp. 3445). Thousand Oaks, CA: Sage Publications.

Francis, L. J., \& Katz, Y. J. (2002). Religiosity and happiness: As study among Israeli female undergraduates. Research in the Social Scientific Study of Religion, vol. 13, 75-86.

Francis, L. J., \& Robbins, M. (2000). Religion and happiness: A study in empirical theology. Transpersonal Psychology Review, vol. 4, 17-22.

Goossens, L. (2001). Global versus domain-specific statuses in identity research: A comparison of two selfreport measures. Journal of Adolescence, vol. 24, 681-699. 
Griffith, B. A., \& Griggs, J. C. (2001). Religious identity status as a model to understand, assess, and interact with client spirituality. Counseling and Values, vol. 46, 1, 14.

Hackney, C., \& Sanders, G. (2003). Religiosity and mental health: A meta-analysis of recent studies. Journal for the Scientific Study of Religion, vol. 42, 43-55.

Helm, H., Hays, J. C., Flint, E., Koenig, H. G., \& Blazer, D. G. (2000). Effects of private religious activity on mortality of elderly disabled and non-disabled adults. Journal of Gerontology, vol. 55A, M400M405.

Indrawati, E., Setyorini, S., \& Padmomartono, S. (2014). Meningkatkan Perilaku Asertif Menggunakan Pendekatan Behavioral dengan Latihan Asertif pada Siswa Kelas IX SMP Negeri 2 Salatiga. Satya Widya, 30(1), 1-12.

Koenig, H. G., \& Larson, D. B. (2001). Religion and mental health: Evidence of association. International Review of Psychiatry, vol. 13, 67-78.

Leondari, A., \& Gialamas, V. (2009). Religiosity and psychological well-being. International Journal of Psychology, no. 44, vol. 4, 241-8.

Lewis, C. A., Maltby, J., \& Day, L. (2005). Religious orientation, religious coping, and happiness among UK adults. Personality and Individual Differences, vol. 38, 1193-1202.

Luyckx, K., Goossens, L., Soenens, B., Beyers, W., \& Vansteenkiste, M. (2005). Identity statuses based on 4 rather than 2 identity dimensions: Extending and refining Marcia's paradigm. Journal of Youth and Adolescence, 34, 605-618.

Luyckx, K., Schwartz, S. J., Goossens, L., Soenens, B., \& Beyers, W. (2008). Developmental typologies of identity formation and adjustment in female emerging adults: A latent class growth analysis approach. Journal of Research on Adolescence, 18, 595 - 619.

Marcia, J. E. (1993). The ego identity status approach to ego identity. Dalam Marcia, J. E., Waterman, A. S., Matteson, D. R., Archer, S. L., Orlofsky, J. L. Ego identity, A Handbook for Psychosocial Research (pp. 3-21). New York: Springer Verlag.

Marcia, J. E. (2001). A commentary on Seth Schwartz's review of identity theory and research. Identity: An International Journal of Theory and Research, vol. 1, 59-65.

McAdams, D. P., \& Cox, K. S. (2010). Self and identity across the life span. In R. M. Lerner, A. Freund, \& M. Lamb (Eds.), Handbook of life-span development (Vol. 2). New York: Wiley.

Meeus, W. (2011). The study of adolescent identity formation 2000-2010: A review of longitudinal research. Journal of Research in Adolescence, vol. 21, 75-84.

Papalia, D. E., \& Feldman, R. D. (2015). Menyelami Perkembangan Manusia. Jakarta: Salemba Humanika.

Prayitno \& Amti, E. (2004). Dasar-dasar Bimbingan dan Konseling. Jakarta : Rieka Cipta.

Santrock, J. W. (2014). Adolescence (15th ed). New York : McGraw-Hill Companies, Inc.

Schwartz, S. J., Beyers, W., Luyckx, K., Soenens, B., Zamboanga, B. L., Forthun, L. F., Hardy, S. A., Vazsonyi, A. T., Ham, L. S., Kim, S. Y., Whitbourne, S. K., \& Waterman, A. S. (2011). "Examining the light and dark sides of emerging adults' identity: A study of identity status differences in positive and negative psychosocial functioning". Journal of Youth and Adolescence, vol. 40, 839-859.

Swinton, J. (2001). Spirituality and mental health care: Rediscovering a 'forgotten' dimension. London: Jessica Kingsley.

Turina, Giyono, \& Rahmayanti, R. (2015). Penggunaan Teknik Assertive Training dalam Meningkatkan Rasa Percaya Diri pada Siswa Kelas VII di SMP N 29 Bandar Lampung Tahun Pelajaran 2014/2015. Alibkin (Jurnal Bimbingan dan Konseling), 3(4). 